of the Representative Body present and voting was needed as well as the written consent of the diocesan bishop concerned. Given that the Representative Body only meets once a year. the need for a resolution of its members was manifestly inconvenient, and accordingly the Governing Body has agreed that for the future a resolution of threequarters of the members of the Finance and Resources Committee of the Representative Body present and voting shall suffice, subject always to the assent of the diocesan bishop being obtained in writing.

Finally, the Governing Body also received the formal amendments to the Constitution prepared by the Drafting Sub-Committee effecting the changes agreed in April to bring parish accounting practices into line with the requirements of the new legislation on charities. These involved amendments in Volume I to sections 15, 16, 22 and 23 of chapter VI, and the introduction of Church in Wales Accounting Regulations in to Volume II. The amendments to Volume I basically require parishes to observe the requirements of the charities legislation and the regulations, while the regulations themselves set out the current statutory requirements and rules of good practice.

1997 has not been the most exciting of years in terms of legislative developments in the Church in Wales, and perhaps, after the experiences of the immediately previous period. that is no bad thing. Nevertheless, what developments there have been reflect the capacity of a national body both to govern its own affairs and to respond to the perceived needs of its people at a variety of levels, from the village churchyard to the great cathedrals. Perhaps therein lies the message of the disestablished Church to the nation in the year decisive for devolution.

\title{
THE GENERAL SYNOD OF THE EPISCOPAL CHURCH OF SCOTLAND
}

\author{
IVOR GUILD \\ Writer to the Signet
}

After being held in Edinburgh for a number of years the Synod was held in Oban. The change was welcomed as giving an opportunity for greater socialising---not perhaps the primary purpose of the Synod, but nevertheless an important by-product.

Procedural changes were the first matters considered. including the adoption of new Rules of Order for the meetings and the consolidation of the Digest of Resolutions, the body of rules of less than canonical status. Neither change roused protest or enthusiasm. and both were accepted as good practical steps to ensure the smooth running of the Church machinery. An attempt to re-affirm a resolution was thereby ruled out of order when a group tried to reiterate the desirability of women priests. Those expert in the former familiar Rules, however. may feel aggrieved in having to learn afresh the new numbering and wording.

Canonical changes are what give the greatest scope for debate. and none more so than the reworded Canon 4, which sets out the procedure for the election of a bishop. It has been amended repeatedly over the years, but each election shows up some deficiency. This year the Canon came up for confirmation at a second reading. It was indeed passed, but the procedure at the election of a new bishop of Brechin - an election which was at length achieved after the Synod-gave rise to discontent with the Canon even as now amended. It is difficult to evolve a procedure which will give electors a chance of discovering the opinions and character of candidates without being too intrusive and inquisitorial. From one aspect publicity about those allowing their names to go forward is desirable. but not every candidate wants his parish or employing body to know that he has agreed to stand for another job. The requirement that the successful candidate must obtain a majority of the votes in both the clerical and 
lay Houses is a reasonable one, but can lead to an impasse when the choice of clergy and lay people differ, and may require a fresh start to the whole procedure. The amendments provide for the possibility of introducing new names and reintroducing old names in the course of the election process and aim to obtain a decision within 142 days of the vacancy. The emphasis of the Canon is to remind electors to bear in mind not only the wishes of the diocese, but also the needs of the Province.

\section{Other Canons}

The Scottish Church, small as it is, consists of seven dioceses. An attempt to reduce the number to six recently roused great indignation and, while the authority to decide such a step remains with the Episcopal Synod, a Canon has been enacted, despite the disapproval of one diocese, under which any change in number or boundaries of dioceses should be submitted to the Administration Board for a report on the financial consequences and to diocesan synods for comment, before it is submitted to the General Synod.

Another canonical charge relates to charges in which a vacancy occurred at a time when the charge is unable to meet the clergy stipend. Periods of suspension have been introduced.

After discussion in the dioceses the scope for ecumenical projects was also enlarged so that with the bishop's authority such experiments with other Trinitarian churches could be embarked on.

Perhaps the most important canonical change concerns Offences and Accusations of the Clergy. The existing Canon is brief, and it is thought that both offences and the procedure relating to the prosecution of them should be spelled out in more precise form. The proposed Canon was discussed and passed for the first time. It will involve the setting up of a Clergy Discipline Tribunal and provision for appeals from it. Appendices contain the forms to be used at each stage.

Of a less formal nature is a paper in course of preparation on how cases of pastoral problems or breakdown at congregational and diocesan level can be dealt with sensitively and with the minimum of fuss and rigidity.

\section{Gender inclusive language}

From the preceding year there had been carried forward the alteration of the 1982 Scottish Liturgy by the introduction of inclusive language. This had been sent down to dioceses in 1996. and various dioceses had expressed strong views. One diocese considered that there should be an opportunity for further study, another that the proposed changes were premature. and. if made. should be merely permissive. One of the largest dioceses showed a "negative attitude" towards the proposed changes, and stressed the continuing use of received biblical imagery of the Fatherhood of God. A motion that new liturgical texts be prepared was defeated, and instead the Faith and Order Board has set up a working group to write a longer study guide on the subject of language in the Church. the guide to be ready for discussion at diocesan synods in 1998.

\section{Terms of Emplorment}

Satisfaction was expressed that as a result of an increase of stipend of over 4 per cent parity was being established with stipends in the Church of England. But the whole conditions of service of the clergy were under review. and a paper had been circulated offering new "Guidelines for the filling of vacancies". The relationship of the bishop to the stipendiary clergy. and of the rector to his vestry. was discussed. Terms of employment with the possibility of contracts of employment were part of the discussion. and also whether clerical remuneration should be looked at more as a package 
of stipend, housing, pension and allowances. Proper use of stipendiary resources was debated; it was felt that there should be greater planning of career, continuing training and expectations-very much the aspects which affect those in other professions.

\title{
Theological Institute
}

The Theological College was closed several years ago and instead a Theological Institute opened alongside a Church of Scotland college. It was decided to remove the Institute to Old Coates House, a listed building close to St Mary's Cathedral where there would be a greater working space and some living accommodation for full-time students. It was hoped to reconstitute the working library there. Staff would be increased, but there would be no return to the old pattern of working. Despite the move the Episcopal Church would remain committed to Scottish Churches Open College.

It need scarcely be added that fund-raising, as always, was a subject of debate. Not unconnected with it was the final authorisation of the service of Administration of Communion by a deacon or lay person, which had previously been tried on an experimental basis in charges where there was no priest to preside at the Eucharist; communion was then administered from the Reserved Sacrament. This is an important provision in the sparsely populated parts of the country.

None of this reflects the beauty of the countryside round Oban or the warm hospitality of the Argyllshire congregations. The anniversary of St Columba's arrival was not forgotten, and the greater socialising was indeed enjoyed, but the Synod will return to Edinburgh next year.

\section{THE GENERAL SYNOD OF THE CHURCH OF ENGLAND}

\author{
BRIAN HANSON \\ Registrar and Legal Adviser to the General Synod
}

This Report covers two Groups of Sessions held in July and November 1997.

The Pensions Measure 1997 (No. 1), which was given Final Approval by the General Synod in November 1996 (see 4 Ecc LJ 681). received the Royal Assent on 21 March 1997 and comes into force on I January 1998. At the July Sessions the Church of England Pensions Regulations 1997. SI 1997/1929. made pursuant to the Clergy Pensions (Amendment) Measure 1972. and various other amending rules required as a result of the new legislation. were passed by the Synod.

The Churchwardens Measure which had its revision stage at the July and November 1996 Sessions (see 4 Ecc LJ 681) received Final Approval in July 1997 (Bishops 26. 0; Clergy 148, 5: Laity 181. 6). The Measure now awaits consideration by the Ecclesiastical Committee of Parliament.

The Cathedrals Measure which had been Generally Approved by the Synod in November 1996 (see 4 Ecc LJ 682) returned to the Synod on the Revision Stage in July. Through lack of time the revision stage had to be adjourned and was completed at the November Sessions.

Also considered on the Revision Stage in November was the National Institutions Measure which had been Generally Approved at the previous November Sessions (see 4 Ecc LJ 20 p. 682). The Measure was returned to the Synod by the Revision Committee with the position of the Synod strengthened and enhanced by the proposals. During the Revision Committee stage there had been input both from the dioceses and from parliamentarians. The revised Measure safeguards the Synod's power of legislative initiative and the 